\title{
Microbial analysis of poultry feeds produced in songhai farms, rivers state, Nigeria
}

\begin{abstract}
Ingestion of contaminated poultry feeds are important route of poultry bird's infection, a total of 50 samples of Quails, Broilers, Layers, and Sussex feeds produced in Songhai farms, Rivers State were analyzed for their bacterial and fungal quality using the culture plate method. The bacteria isolated were Escherichia coli, Staphylococcus aureus, Bacillus spp, Lactobacillus spp, Salmonella spp, the highest percentage of occurrence was obtained with Staphylococcus aureus 35.6\%. The fungi isolated were Aspergillus spp, Rhizopus spp, Penicillium spp, Mucor spp. The highest bacteria and fungi count was obtained in Broilers $5.4 \times 10^{5} \mathrm{cfu} / \mathrm{g}$ and $8.1 \times 10^{5} \mathrm{cfu} / \mathrm{g}$ respectively while the least count was recorded in Sussex with the range $2.19 \times 10^{5} \mathrm{cfu} / \mathrm{g}$ (bacteria) and $5.7 \times 10^{5} \mathrm{cfu} / \mathrm{g}$ (fungi). All the fungi isolated are potentially toxigenic and the fungi count is above the hygienic indicator level, most bacteria isolated are always being implicated in poultry farming disease outbreak. Therefore it is necessary to adopt a microbial quality control measure especially during feed formulation process.
\end{abstract}

Keywords: bacteria, fungi, poultry feeds, pathogens, songhai farm
Volume 4 Issue 2 - 2017

\section{Osaro Matthew, Ruth Chiamaka, Otiekwe chidinma}

Department of microbiology, Michael Okpara University of Agriculture Umudike, Nigeria

\author{
Correspondence: Osaro-Matthew, Department of \\ microbiology, college of natural science, Michael Okpara \\ University of Agriculture Umudike, Nigeria, \\ Emailmrc.osaro@mouau.edu.ng, mensahuche@yahoo.com
}

Received: April 12, 2016 | Published: March 06, 2017
Abbreviations: MRS, deman rogosa sharpe; SDA, sabouraud dextrose agar; SSA, salmonella shigella agar; cfu: colony forming units

\section{Introduction}

Poultry feeds are formulated in other to meet the complex nutrient requirements of birds. Due to the simple digestive tract of birds and the intestinal flora making little contribution towards food digestion, it is necessary that poultry feed is complete (nutrients necessary for proper growth and egg production) and easily digestible. ${ }^{1}$ Materials for formulation of feeds are sourced from different origin both animals and plants and are mostly agro wastes. ${ }^{2}$

However, most of these feed additives have been implicated amongst the principle sources of microorganisms of public health concern. $^{3}$

Presence of microorganisms in the feed might be attributed to the normal flora of the feed, cross contamination or questionable water quality. More so owing to the importance of probiotics there could be deliberate incorporation of these (Lactic acid bacteria) into the feed.

Accordingly, several poultry diseases with various pathological manifestations and of different origins: viral (e.g. Avian influenza, Newcastle disease), Bacterial (e.g. Salmonellosis and infectious coryza) and fungal origin (e.g Aspergillosis, Candidiasis and Histoplasmosis, also consumption of mycotoxins can cause immunosuppression), have been attributed to poultry feeds. ${ }^{4,5}$

In the Western and Eastern Nigeria Arotupin et al. ${ }^{6}$ and AdebayoTayo \& Ettah ${ }^{7}$ autonomously isolated pathogenic bacteria genera and species from the poultry feed samples sold in that part of the country. Considering the health effect of contaminated feed on the birds, consumers of the poultry products, it becomes important to undertake this study.

\section{Materials and methods}

\section{Study area}

The farm is located at Ogoni about longitude $7^{\circ} 13^{\prime}$ East and latitude $4^{0} 44^{\prime}$ North the east of the city of Port Harcourt. in Rivers state. It extends across the local government areas; Khana, Gokhana, Eleme, and Tai. ${ }^{8}$

\section{Collection of samples}

A total of fifty (50) samples of poultry feed of four (4) different birds: Quail (10), Sussex (10), broilers (15), and layers (15) were collected from Songhai farms using sterile containers. Specimens were adequately labeled to reflect the particular bird.

\section{Isolation microorganisms}

Samples were processed according to Ogbulie et al..$^{9}$ One gram of each sample was homogenized in $9 \mathrm{ml}$ of sterile physiological saline, serial dilution carried out to $10^{-5}$ dilution. One $\mathrm{ml}$ of the solution was inoculated onto already prepared and solidified MacConkey agar, DeMan Rogosa Sharpe agar (MRS), Sabouraud Dextrose agar (SDA), Salmonella Shigella agar (SSA) using spread plate method, and incubated for 24 hours at $37^{\circ} \mathrm{C}$, SDA plates were incubated at $25^{\circ} \mathrm{C}$ for 3-7 days. Using the viable plate count method, plate counts of 30300 colony forming units (cfu) were reported.

\section{Identification of bacterial and fungal isolates}

Bacterial isolates were identified base on their Gram staining and biochemical characteristics (indole test, sugar fermentation, methyl red test, voges- proskauer test, catalase test, coagulase test, citrate test) and compared with criteria in Bergey's Manual of Determinative Bacteriology (1994), fungal isolates were identified base on their morphological characteristics on SDA and Lactophenol cotton blue stain identification and compared with criteria in Barnett et al. ${ }^{10}$

\section{Results}

The mean bacterial and fungal counts of the feed samples produced in Songhai farms with their varying range are represented in Table 1 , the highest mean bacterial count and fungal count was obtained in Broiler $\left(5.4 \times 10^{5} \mathrm{cfu} / \mathrm{g}\right)$ and $\left(8.1 \times 10^{5} \mathrm{cfu} / \mathrm{g}\right)$ respectively while the least was obtained in sussex $\left(2.19 \times 10^{5} \mathrm{cfu} / \mathrm{g}\right)$ and $\left(5.7 \times 10^{5} \mathrm{cfu} / \mathrm{g}\right)$ respectively. 
The percentage occurrence of bacteria on the poultry feed samples from Songhai farms is represented in Table 2, which also presented the five genera of bacteria was isolated from the feed samples which include: Escherichia, Salmonella,

Staphylococcus, Lactobacillus and Bacillus, of which $S$. Aureus has the highest frequency of occurrence $(35.6 \%)$ while Bacillus spp, Escherichia coli and Lactobacillus spp has the same frequency of occurrence $(11.1 \%)$ which is the least.

Presented in Table 3 is the distribution of fungi on the of poultry feeds, showing four isolated genera of which include Aspergillus, Rhizopus, Mucor and Penicillium, Rhizopus spp has the highest distribution frequency (37.5\%) while Penicillium spp has the least distribution frequency $(14.6 \%)$.

Table I Mean total bacteria count and fungi count of poultry feed samples

\begin{tabular}{lll}
\hline Poultry Feed & Bacteria (Cfu/G) & Fungi (Cfu/G) \\
\hline Quails & $2.9 \times 10^{5}$ & $7.4 \times 10^{5}$ \\
Broilers & $5.4 \times 10^{5}$ & $8.1 \times 10^{5}$ \\
Layers & $4.2 \times 10^{5}$ & $7.1 \times 10^{5}$ \\
Sussex & $2.19 \times 10^{5}$ & $5.7 \times 10^{5}$ \\
\hline
\end{tabular}

Table 2 Frequency of occurrence of bacteria in poultry feed samples

\begin{tabular}{|c|c|c|c|c|c|c|}
\hline \multirow{2}{*}{ Isolates } & \multicolumn{4}{|c|}{ No of Samples Positive } & \multirow{2}{*}{ Frequency } & \multirow{2}{*}{ Frequency (\%) } \\
\hline & $\mathbf{Q}$ & B & $\mathbf{L}$ & $\mathbf{S}$ & & \\
\hline Escherichia coli & I & 2 & 2 & 0 & 5 & II.I \\
\hline Staphylococcus aureus & 5 & 4 & 3 & 4 & 16 & 35.6 \\
\hline Bacillus spp & 2 & 0 & 2 & I & 5 & II.I \\
\hline Lactobacillus spp & 0 & 2 & 3 & 0 & 5 & II.I \\
\hline Salmonella spp & 2 & 4 & 5 & 3 & 14 & 31.1 \\
\hline
\end{tabular}

Key: $Q=$ Quails $B=$ Broilers $L=$ Layers $S=$ Sussex.

Total no of samples $=50$.

Table 3 Percentage occurrence of fungi in poultry feed samples

\begin{tabular}{lllllll}
\hline & \multicolumn{9}{l}{ No of Samples Positive } & \multicolumn{2}{c}{ Frequency } & Frequency (\%) \\
Isolates & Q & B & L & S & 10 & 20.8 \\
Aspergillus spp. & 6 & 2 & 3 & 2 & 18 & 37.5 \\
Rhizopus spp. & 3 & 3 & 5 & 4 & 7 & 14.6 \\
Penicillium spp. & 0 & 4 & 3 & 0 & 13 & 27.1 \\
Mucor spp. & 0 & 6 & 3 & 4 & \\
\hline
\end{tabular}

Key:Q=Quails B=Broilers $L=$ Layers $S=$ Sussex.

Total no of samples $=50$.

\section{Discussion}

Most times poultry birds get infected through consumption of contaminated feeds, making the quality and safety of poultry feeds important part of poultry farming. All samples analyzed in this study showed the presence of microorganisms, which is an indication that poultry feeds serve as good growth medium for microorganisms owing to the nutritional quality. The result of this study may suggest that both bacteria and fungi might be implicated in health problems on the farm.

D Mello ${ }^{11}$ attributed presence of microorganisms in poultry feeds to climatic conditions, harvesting of raw materials, feed formulation process, storage and transport technologies employed.

Most of the microorganisms isolated in this study have been associated with diseases of the poultry farm. Salmonellosis is caused by bacterium of the genera Salmonella, this infection is common in two weeks old chicks and ducklings, Salmonella gastroenteritis of human have been associated with consumption of infected birds, hence the infection of birds with Salmonella has been attributed to contaminated feeds. ${ }^{12}$ Isolation of $E$. coli a coliform is an indication of feacal material contamination which can be associated with poor hygiene.

Bacillus spp and Staphylococcus aureus have been implicated by the studies of Dhand et al. ${ }^{14}$ in the poultry farming microbial disease outbreak., Staphylococcus aureus was the most prevalent which is in agreement with the result of Arotupin et al. ${ }^{6}$ and Mahmudullah et al. ${ }^{13}$ The presence of Lactobacillus spp can be attributed to normal flora of raw material especially of plants origin, it cannot be said to be as a result of deliberate incorporation of lactic acid bacteria as probiotics since it was not isolated from all the feed samples. Dhand et al. ${ }^{14}$ reported the beneficial effect of lactic acid bacteria on poultry feed.

The isolation of fungi genera (Aspergillus, Mucor, Rhizopus and Penicillium) which could be mycotoxigenic from the poultry feeds can be linked to cereal raw materials used in feed formulation, mycotoxins are economically important toxins which are immunosuppressive and can result to low poultry production. Aspergillus spp can also cause aspergillosis in birds the presence of Aspergillus spp in food should be of a concern, ${ }^{6}$ Dhand et al. ${ }^{14}$ reported it to be leading in respect to mycotoxin production in poultry feeds. 
Rhizopus spp and Mucor spp were the predominant fungi in this study which might cause deterioration of the feeds ingredients making less nutrients available for the birds. Also some species of Rhizopus are mycotoxigenic. The least fungal count was obtained in Sussex value $5.7 \times 10^{5} \mathrm{cfu} / \mathrm{g}$, which exceeds the safety quality indicator of total fungi count less than or equal to $1 \times 10^{5} \mathrm{cfu} / \mathrm{g} .{ }^{13}$ The bacterial count was highest in broilers at $5.4 \times 10^{6} \mathrm{cfu} / \mathrm{g}$ and least in Sussex at $2.19 \times 10^{5} \mathrm{cfu} / \mathrm{g}$, The reported high microbial count in broilers feed is in line with the findings of Arotupin et al. ${ }^{6}$ and maybe depicts the level at which the ingredients used in the feeds production is contaminated, more so the use of agro wastes such as fish waste, cassava flour, bone meal, millet, lysine, maize, wheat offal, oyster shell, fish meal, groundnut cake, palm kernel cake, soya bean cake, brewery waste. ${ }^{15}$ The high level of fungi obtained in this study can be as a result of low water activity of the poultry feed.

\section{Conclusion}

In the course of this study many of the bacteria isolated are pathogenic and most fungi isolated are potentially toxigenic while few lactic acid bacteria which are considered as health promoting bacteria were isolated, making it a necessity to establish a quality control algorithm to be adopted during feed formulation, storage and use and equally educate local farmers on how to apply this strategy and equally adopting the practice of incorporation of probiotics into feed. This will enhance poultry farm production and reduce the incidence of human diseases associated with poultry product consumption.

\section{Conflicts of Interest}

The authors declare no conflict of interest.

\section{Acknowledgments}

None.

\section{Funding}

None.

\section{References}

1. Smith HV, Patterson WJR, Hardie LA, et al. An outbreak of waterborne cryptosporidiosis caused by post-treatment contamination. Epidemiol Infect. 2005;103(3):703-715.
2. Afolayan MO, Afolayan M. Nigeria Oreinted Poultry Feed Formulation Software Requirements. Journal of AppliedSciences Research. 2008;4(11):1596-1602.

3. Bangladash GS. Antibiotic use in agriculture:background and legislation. Congressional Research Service Report for Congress R. 2009;40739, p. $1-15$.

4. Macrowioski KG, Herrera P, Jones FT, et al. Effects on poultry and Livestock of feed contamination with bacteria and fungi. Animal Feeds Scienceand Technology. 2006;133(1-2):109-136.

5. Singh SD, Tiwari R, Dhama K. Mycotoxins and Mycotoxicosis-impact on poultry Health and production. An overview of poultry Punch. 2012;28:35-52.

6. Arotupin DJ, Kayode RMO, Awojobi KO. Microbiological and Physicochemical qualities of selected commercial of selected commercial poultry feeds in Akure, Nigeria. Nigeria Journal of Biological Science. 2007;7(6):981-984.

7. Adebayo Tayo BC, Ettah AE. Microbiological Quality and Aflatoxin B1 level in Poultry and Livestock feeds. Nigerian Journal of Microbiology. 2010;24(1):2145-2152.

8. Vobnu SK. Origin and languages of Ogoni People. Boori, KHALGA, Ogoni and languages Bible center, Nigeria. 2007.

9. Ogbulie JN, Okpokwasili GC. Haematological and histological responses of Clarias gariepinus and Heterobranchus bidorsalis to some bacterial diseases in Rivers State , Nigeria. Journal of the National Science Foundation of Sri Lanka. 1999;27(1):1-61.

10. Barnett HL, Hunter BB (1972) Classification of fungi imperfect. ( $3^{\text {rd }}$ edn), Burges Publishing Company Minneapolis, USA, pp. 331.

11. D mello JFP. Microbiology of Animal Feeds. Microbiology of Ensilage. 2006.

12. Pattison M. McMullin P, Bradbury J, et al. Poultry diseases. 6th edn, Butterworth Heinemann, USA. 2008;110-115.

13. Mahmudullah B, Rupomanjury S, Shafqul I, et al. Prevalence of microflora and potentially toxigenic fungi in poultry feed mixtures. Annals Food Science and Technology. 2015;16(1):267-273.

14. Dhand NK, Joshi DV, Jand SK. Aflatoxin in Dairy feeds/ingredients . Indian Journal of Animal Sceince. 1998;15(4):285-286.

15. Jeffery JS, Kirk JH, Atiwill ER, et al. Prevalence of selected microbial pathogens in processed poultry waste used as diary cattle feed. Poultry Sciences. 2008;77(6):808-811 